\title{
21 \\ CAN E-MARKETPLACES BRIDGE THE DIGITAL DIVIDE?
}

\author{
C. Standing ${ }^{1}$, I. Sims ${ }^{1}$, R. Stockdale ${ }^{1}$ and A. Wassenaar ${ }^{2}$ \\ ${ }^{l}$ School of MIS, Edith Cowan University, AU; ${ }^{2}$ Department of Business Information Systems, \\ University of Twente, $N L$.
}

\begin{abstract}
In Australia, small and medium enterprises (SMEs), particularly rural SMEs, are perceived as being on the wrong side of the digital divide. Government at local and state levels have taken a leading role in the development of electronic marketplaces with an aim of improving the lot for SMEs. Many government departments now either own or sponsor electronic marketplaces. Government aims in creating e-marketplaces are often motivated by regional economic development issues. Whilst government entities may think emarketplaces are an effective channel for implementing government policy a number of complications can arise from this model, not least is being seen as stifling free trade. Despite the community development motivation a major argument for e-marketplace development being put forward is the economic one and this has contributed to a narrow view of the e-marketplace concept and one, which for the time being at least, is likely to restrict its impact. Government sponsored e-marketplaces should consider the value of on-line business networks to share knowledge and potentially increase levels of innovation.
\end{abstract}

Keywords: SMEs, electronic marketplaces, government, digital divide.

\section{INTRODUCTION}

Within Australia the term "digital divide" is used to describe the gap between the level of sophistication in IT and e-business adoption and usage in rural compared with urban areas and small and medium enterprises (SMEs) compared with large companies. The severity of the issues are expressed in a range of government sponsored reports and reflected by a 
range of government funding opportunities to address the problems (Curtin, 2001; DoIT, 2001). In Western Australia, State government and city councils have got involved in developing electronic marketplaces with a key aim of encouraging the development of the SME sector and narrowing the digital divide between SMEs and their larger counterparts. Regional commissions in other areas of Western Australia are now beginning to look at the potential of electronic marketplaces to address the digital divide in their own localities.

This paper examines the potential of electronic marketplaces to address the "SME problem" and in particular the "rural SME problem" in Australia. The first section explains the nature of the problems that face the SME sector, which are exacerbated in rural communities. The second section of the paper presents various definitions of e-marketplaces followed by an examination of marketplace ownership structures. Two government sponsored electronic marketplaces are examined to draw out lessons that can be learned for regional commissions thinking of developing their own emarketplaces. The implications of the findings are discussed in relation to how effective these strategies are for lessening the digital divide within Australia.

\section{THE AUSTRALIAN DIGITAL DIVIDE}

The digital divide within Australian society exists on a number of levels. Two related forms of the divide exist in relation to the IT/IS sophistication of SMEs compared with large companies and also the IT/IS sophistication of rural Australia compared with the major metropolitan centres (Curtin, 2001; DoIT, 2001; NOIE, 2002). The two are clearly interlinked and are compounded in rural Australia since most rural businesses are SMEs. This section of the paper presents information on the IT/IS sophistication in the SME and rural sectors.

Ongoing research indicates that even where SMEs have some awareness and use of e-commerce there still remain problems (Bode and Burn, 2001; Tetteh and Burn, 2001). Research reports indicate that lack of access to advice on Internet strategy is seen as a major barrier by SMEs (van Akkeren and Cavaye, 1999) and only approximately one third of Web enabled SMEs have any form of an Internet strategy (Kinnes, 2001; Stokes, 2000). SME websites are primarily information sites for customers and only $20 \%$ are capable of taking an order online (Korchak and Rodman, 2001). There is little awareness that e-commerce offers companies "unprecedented access to information on IT" (Swatman, 2000). 
Less than a third of SMEs use the Web for procurement and there has been low penetration of e-marketplaces. Although e-marketplaces are being increasingly used by large organisations, which have been quick to realise their potential, SMEs have been slow to take up their adoption as a mechanism for buying and selling. Some argue that SMEs are disadvantaged in tendering for large projects, especially government ones, because of their difficulties in areas such as the financial and legal requirements of contracts, software compatibility and their inability to partner and thereby provide as competitive a service as larger companies (Davidson, 2002). Poor performance in winning large government contracts has exacerbated the SME digital divide.

Many of the problems relating to the failure of SMEs to address the importance of electronic marketplaces lies in a lack of understanding of the advantages and how they can benefit from them. SMEs understanding of the global marketplace is 'not good enough' (Erbschloe, 1999) and they lack sufficient awareness of the nature of the Internet and how it interacts with other methods of trading. Smaller companies do not see themselves as part of a large supply chain and they underestimate how the Internet can benefit them by sharing information, buying from suppliers with no paper system, electronic fulfilment, tracking, and efficiencies in cost and time (Jack, 2001). If they do not understand their ability to function within the larger supply chain they will lose out to large firms in electronic markets (Korchak and Rodman, 2001). The developing world markets brought about by ecommerce, and the increased ability to trade globally facilitated by electronic markets, adds to pressure on the SMEs by increasing the number of firms with the ability to trade in each region (Said, 2000).

The problems associated with the SME sector in Australia are exacerbated in rural areas (Curtin, 2001), where markets, expertise, general business support, IT support and specialist consultancy services are limited. Poor telecommunications infrastructure is also cited as a major barrier to ecommerce adoption. Although there is no denying these problems many opportunities are lost because of a lack of awareness and expertise in ebusiness.

The extensive economic and social benefits of effective e-marketplace participation for rural SMEs include reduced costs (reportedly by a 'factor of five or ten or more' (Lucking-Reiley and Spulber, 2000), improved customer service, reduced communication costs, accelerated flow of news and information and improved market information. These benefits stem from participation in e-marketplaces with a transaction and value-added information focus. However, other types of network/marketplace participation can produce substantial benefits for organisations since the knowledge and expertise that is shared within the network can stimulate new 
levels of business innovation. These business benefits are supplemented by definable social benefits where the interconnectedness that is a feature of what Raisch (2001) terms Value Trust Networks (VTNs) can contribute to stability and self-esteem in rural communities (Lewis, 2001).

Success in extending the markets of rural industries will bring major benefits both to the businesses and to the community. Conversely, failure to compete in value trust networks will result in regional isolation as the increased ability to interact globally adds to the pressure of competition from other regions.

\section{DEFINING ELECTRONIC MARKETPLACES}

Before examining government sponsored e-marketplace initiatives in Western Australia we briefly analyse various definitions and e-marketplace concepts. The proliferation of electronic marketplaces in the last five years has been rapid and extensive, although an anticipated period of consolidation is taking place (Forrester Research, 2000). The rapid emergence of this topic has led to a diverse range of definitions highlighting differing perspectives such as the role of the stakeholders (Federal Trade Commission, 2000) or the interactivity of business communities (Brunn et al., 2002). However, Bakos' definition of an electronic marketplace as 'an interorganisational information system that allows the participating buyers and sellers in some market to exchange information about prices and product offerings' retains simplicity but manages to encompass the essence of marketplace activity (Bakos, 1997). It is important to distinguish between a market and a marketplace. A market covers the supply and demand for a product or service but a marketplace is a bounded entity that provides specific mechanisms for the exchange, hence any market could have one or a number of marketplaces associated with it.

The level of e-marketplace activity has been evolving from early matchmaking models to more complex interactive and interconnected marketspaces, which can be termed Value Trust Networks (VTN). Raisch (2001) describes four phases of VTN evolution beginning with a transaction focus at level one that evolves into a value-added marketplace offering transaction support services. The increase in information value-add contributes enhanced industry knowledge and interorganisational collaboration and has the potential for e-marketplaces to develop into a third phase. This will see services enhanced by capturing and utilising rich information flows and creating knowledge exchanges. The ability to integrate the transaction exchange, the value-add services and the knowledge services moves the evolution of e-marketplaces into Raisch's fourth phase. 
VTNs offer the promise of a new business platform of integrated and interconnected business communities that will spawn a new era of business innovation (Raisch, 2001). Although Raisch proposes this as an evolutionary model no research has been conducted to verify this as far as the authors are aware. Therefore, it is safer to assume that the four levels represent different functionalities within a complex e-marketplace/network arrangement without being evolutionary in nature.

The roles of electronic marketplace participants are not necessarily mutually exclusive since for example, a buyer could also be a seller and vice versa and a market maker (owner) could also be a buyer and/or a seller. These overlapping roles have the potential to create role ambiguity and even conflict of interests.

It is assumed that an e-marketplace governance structure is either biased or neutral (Kaplan and Sawhney, 2000) and that private e-marketplaces will be, at least to some extent, biased in favour of the owner, and public emarketplaces will either be biased in favour of buyers or sellers or be neutral. It is suggested that it is in the interests of e-marketplaces to be neutral, neither favouring buyers nor sellers (Sculley and Woods, 2001). The benefits of a neutral marketplace are seen as a perception of fairness, which impacts on increased trust between trading participants. In addition, fewer channel conflict issues are expected to arise due to increased transparency and better exploitation of market and supply chain efficiencies (Brunn et al., 2002).

\section{EVALUATION OF BENEFITS CONCEPTS}

Benefits can be broadly classified according to whether they produce economic, network, service, or community advantages. Market makers may have one or a variety of motives in creating and maintaining an electronic marketplace. Each potential motive is discussed below.

\subsection{Economic Motive}

Initial incentives for the development of an interorganisational information system are economic and involve three potential benefits for participants; cost reductions, productivity improvements and product/market strategy (Barrett and Konsynski, 1982). The economic motive for engaging in e-marketplaces is bound up with transaction cost economics. Simply, the costs of a business fall into two categories: production costs and transaction costs. Production costs are concerned with the process of transforming inputs into outputs. Transaction costs are the costs associated with finding 
someone with whom to do business, reaching an agreement about the price and other aspects of the exchange, and ensuring that the terms of the agreement are fulfilled (McTaggart et al., 1996). The early pioneer in this area is Ronald Coase who contends that it is impossible to understand the workings of the economic system without taking into account transaction costs (Coase, 1937).

A key work on transaction cost economics (Williamson, 1979) identifies the critical characteristics of a transaction and links these to the institutional governance structure of transactions. The significant characteristics of a transaction are uncertainty, frequency of exchange and the extent to which investments are specific to certain transactions. According to Williamson, non-specific transactions are efficiently organised by markets, while recurrent specific transactions are more efficiently governed internally. Porter (2001) argues the main economic benefits of e-marketplace participation for buyers are low transactions costs and sometimes the ability to pool markets, while for sellers the benefits are lower selling costs, lower transaction costs and access to wider markets. Although there are other motives beyond the economic for owning an e-marketplace they each have economic implications.

\subsection{Network View}

The network view of electronic marketplaces focuses on the relationships and communication infrastructure of groups of organizations, which are bound together in some way. Interorganisational alliances are a form of network with social, political and economic implications. Here, the focus is on the socio-political arrangement. Oliver (1990) proposes six generalisable determinants of interorganisational relationships:

- Necessity to fulfil legal or regulatory requirements

- Asymmetry potential to exert power over other organisations

- Reciprocity desire to cooperate, collaborate and coordinate

- Efficiency internally focused efficiencies

- Stability in response to environmental uncertainty

- Legitimacy related to reputation, image, prestige, or congruence with prevailing norms in the environment

\subsection{Service Motive}

The service motive is concerned with providing a better service to customers, which may include such things as continuity of supply, convenience and speed of processing and greater choice for buyers. The service motive is closely aligned to the economic but is kept separate as this 
may not always be the case. Higher service typically comes at a cost but in theory an organization could choose to deliver higher levels of service despite this extra cost. There are five dimensions by which consumers evaluate service quality (Bebko, 2000; Berry and Parasuraman, 1991):

i. Tangibles. The appearance of physical facilities, equipment, personnel and communications materials.

ii. Reliability. The ability to perform the promised service dependably and accurately.

iii. Responsiveness. Providing a prompt service and desire to help customers.

iv. Assurance. The knowledge and courtesy of employees and their ability to convey trust and confidence.

v. Empathy. The caring individualized attention the firm provides its customers.

In relation to e-marketplaces service quality relates to such things as the Web site and e-marketplace software, personnel, marketing literature and supporting documentation, the reliability of the system and help provided.

\subsection{Community Motive}

Some e-marketplaces are created with a community emphasis. In other words a major objective of the electronic market is to play a role in the development of a community. This is usually done through stimulating economic activity working on the premise that if local/regional business flourishes then so will the communities they are part of. The market maker, usually local or state government, provides encouragement to adopt emarketplace trading and in doing so raise the level of general e-business knowledge, skills and technologies within the business community.

\subsection{Hybrid Arrangement}

Of course, a market maker may have a set of objectives to achieve in the construction and management of the electronic marketplace. For example, the community model may be seen as being for the common good of the society or business community but may still need to be economically viable.

Issues such as trust between participants, information systems architectures, revenue models and transaction mechanisms are all features, which can be used to support the primary motive. 


\section{CASE STUDY APPROACH}

Two examples of e-marketplace development have been selected to illustrate the range of government motivations behind developing emarketplaces in Western Australia. Although examined as extensive case studies, we present the cases here as vignettes (Barter and Renold, 1999) to examine the range of aims, objectives and perceived benefits resulting from e-marketplace creation. Vignettes can take a number of forms. In this paper we use them as concrete examples, which allow the situational context to be explored and influential issues to be identified (Finch, 1987). The original case studies involved the collection of information from official documents and reports, as well as through face-to-face discussions, email correspondence, and attendance at meetings with the e-marketplace sponsors and developers, and the official Web sites of the organisations.

\subsection{Vignette 1: Government Electronic Marketplace (GEM)}

The Western Australian Government currently spends approximately $\$$ A5 billion on goods and services and estimates an average transaction cost for simple purchases of $\$ 100$ (DoIT, 2002).

Early in 2000 the WA government agency responsible for management of government purchasing, the Department of Contract and Management Services (CAMS), embarked on the development of a major project known as the Government Electronic Marketplace (GEM) (DoIT, 2002). In July 2001, as a result of a major government reorganisation the Department of Industry and Technology (DoIT) assumed responsibility for GEM. GEM is Australia's first comprehensive online government buying service and provides an array of services that cover the range of government buying:

- Purchasing of low value commodities

- Public tendering for high value goods and services

- Contract planning, formation and ongoing management (coming soon)

GEM aims to streamline traditional business partnerships between the public and private sectors and significantly enhance the quality, timeliness and cost-effectiveness of services to the community. The published objectives and benefits of the system, listed on the DoIT web site, (DoIT, 2002) are:

- Saving taxpayers money through the introduction of more efficient procurement practices. 
- Increasing the accountability and transparency of government purchasing

- Increasing the levels of compliance with State Supply Commission procurement and purchasing policy (including buy local and common usage contract policies)

- Demonstrating leadership in the implementation of the Australian Procurement and Construction Council (APCC) guidelines and standards for electronic procurement

- Assisting West Australian industry to enter the world of e-commerce in a safe and secure government environment.

- According to the GEM Web site (http://www.gem.com.au):

"Gem gives suppliers access to an enormous market of buyers - initially in government, but ultimately including private schools and hospitals, public benevolent institutions, and third party purchasers such as facilities managers who are looking after government buildings...... Suppliers can rest assured that GEM supports the government's stringent purchasing policies, such as the Buy Local Policy".

The establishment of GEM is not just a tool for implementing market efficiencies, but also for implementing a variety of policies. In the case of GEM, the government owns most of the buyers, some of the sellers and operates the market. To further complicate matters, it also owns the policymaking body that sets the rules for open and effective competition for all government purchasers. This separate body is known as the State Supply Commission.

\subsection{Vignette 2: Regional Electronic Marketplace (REM)}

The twin cities of Joondalup and Wanneroo in WA have developed what they term a regional electronic marketplace (REM), and a significant number of companies have registered to be participants. The REM will be operational in December of 2002. The e-marketplace aims to provide eprocurement and marketing solutions for business, local government and education organisations within the North West corridor of the Perth Metropolitan area. This corridor includes a mixture of suburban and rural communities. The major drivers for the projects are to increase e-commerce adoption, stimulate greater interaction between businesses in the locality, and produce savings and efficiencies for buyers and sellers, all within a local region. A consortium is funding the initial development of REM. This includes North Metro Community Association Incorporated (NMCOA) Online Joondalup and Wanneroo Councils, Edith Cowan University, Joondalup Business Association, Wanneroo Business Association and several other 
local businesses. NMCOA is a not-for-profit incorporated body with most of the sponsors as its founding members.

It is intended that the SME sector will access the REM without high entry cost or EDI compliance barriers; access will be available via a range of communication facilities including Internet, Fax or WAP enabled mobile telephones. The e-marketplace project incorporates three functions:

i. Business to consumer

ii. The e-marketplace will provide local businesses with the opportunity to sell their goods and services to people both inside and outside of the region.

iii. Business to Government

iv. The REM will provide local businesses, who can meet the supply requirements, the opportunity to automatically receive electronic offers to tender or quote for goods and services required by both the City of Joondalup and the City of Wanneroo.

v. Business to business

vi. The same e-marketplace will allow companies to trade with each other electronically.

The key motivations for development of the regional e-marketplace are:

- Increase e-commerce adoption

- The training associated with the e-marketplace will take the form of seminars and laboratory style hands-on sessions. In general, the project aims to improve awareness related to the benefits of emarketplace trading in the region, which is also part of a larger plan to raise e-commerce adoption and knowledge so that companies can become globally competitive

- Improve business efficiency in the locality

- It is anticipated that e-marketplace participation will reduce costs for local businesses and make them more efficient

- Increase trade within the locality

- It is expected that trade within the region will increase as businesses trade more with one another rather than with businesses outside of the region.

- Expansion into new markets

- The City Councils expect that when companies become comfortable with e-marketplace trading they will be more likely to venture into other e-marketplaces and as a result access other state, interstate and international markets.

- Development of the region generally

- It is hoped that the REM will play a role in developing the Northern suburbs as an attractive proposition for new businesses. The Two Cities e-marketplace Web site states: "This facility will encourage 
the growth and retention of jobs within our region by encouraging a more effective "buy local" attitude (http://www.2Cities.com.au).

The 2cities e-marketplace is part of a broader community portal for the Joondalup/Wanneroo cities. This includes functionality supporting aspects of e-government and information about community groups and facilities for them to interact.

\section{DISCUSSION}

The digital divide between rural and urban Australia and the difficulties faced by many SMEs compared with large multi-nationals are two, often related, issues which government at Federal, State and local levels are well aware of. The Western Australian State Government is particularly keen to address the plight of rural SMEs as communities are dependent on how parties at various levels succeed. Electronic marketplace participation is seen by some government agencies as a way of stimulating SME business. The two e-marketplace examples discussed in the paper cover rural and rural/urban fringe areas and have a primary aim of encouraging small business development and growth. In this section of the paper, we discuss the lessons that can be learned from these two WA Government sponsored emarketplaces for examining how WA Regional Commissions and other States can effectively employ e-marketplace business models.

The two electronic marketplaces examined have different ownership structures. In GEM the State Government is the owner but also the buyer. In the 2Cities Regional E-marketplace the city councils of Joondalup and Wanneroo are two of a group of owners. However, they are taking the leading role in setting the direction and in managing the e-marketplace. The lesson for other State governments and city councils is to examine a variety of e-marketplace ownerships models. These may involve using the purchasing power of the government (at whichever level) as a catalyst for emarketplace participation. Alternatively shared ownership arrangements have the advantage of decreasing the development costs and increasing the demand for goods. In addition, shared ownership structures may be seen as more neutral and hence fairer compared with a solely owned marketplace. A potential problem associated with shared ownership is that it may be more difficult to use the e-marketplace to implement government policy such as a buy local strategy. It will be interesting to observe if in the 2Cities REM government objectives are deflected by other members of the group, which may change the emphasis to obtaining the lowest prices rather than regional development. In other words, the main objective could change to an economic rather than a community focus. 
There may be an argument for regional Governments and city councils to serve as information providers and concentrate on disseminating information on e-marketplace participation rather than developing or managing such models. This way SMEs could be exposed to e-marketplaces out of the region with potentially greater returns. The local emphasis to both emarketplaces would seem to be at odds with the generally held views that SMEs should take part in a global business arena. The underlying assumption is that once exposed to e-marketplace trading SMEs will be more likely to take the next step of trading internationally. However, this view of evolutionary participation in e-marketplaces from local to global has not been thoroughly researched and in fact may not be valid.

The view of electronic marketplaces in both cases is one that is transaction focussed (economic) with a minor importance attached to value added information. It is interesting that the Western Australian emarketplaces although being seen as way of building the local community do not highlight or include provision for a strong network model through electronic collaboration and knowledge sharing, in addition to providing access to consultants and digital service providers. Although, the emarketplace owners may wish this to happen there is little mentioned that would facilitate this. This may appear surprising considering the community emphasis.

A value trust network perspective would seem very relevant in fostering SME development and growth. An emphasis on creating value trust networks should be considered by government at state, regional and local levels since the knowledge and expertise that is shared within the network has the potential to create significant levels of innovation. The lesson for government agencies wishing to develop e-marketplaces is to take a broader view of their purpose and to explore ways to create business networks in addition to transaction (selling and procurement) mechanisms.

The main emphasis of the two e-marketplace developments is on the economic motive so that costs can be reduced and potentially markets expanded. This is to be achieved by the reduction in search time for suppliers and a faster transaction process and hence provide a reduction in transaction costs. Porter (2001) warns that buyers may yet turn away from marketplaces to building relationships with fewer suppliers and focus on reducing costs through efficiency gains. Government e-marketplace owners should consider providing advice to the community as to where emarketplaces can be of value and where extranet style arrangements have advantages.

The Joondalup and Wanneroo regional e-marketplace expected that the financial savings accruing to participants would create regional economic stimulus. Just how this will be achieved and sustained is not highlighted in the published reports, documents and Web sites, other than through a 'buy 
local' policy. Government owned e-marketplaces should not assume regional development, and for that matter community development, is an automatic result of e-marketplace participation by SMEs. Indeed, the benefits for the community and region need to be properly evaluated.

The governments appear to see the electronic marketplaces as vehicles to implement policy. This is apparent in GEM and the 2Cities REM. Western Australian Government at State and regional levels are currently promoting buy local policies. It could be argued that this is in conflict with an open market policy. The 2Cities REM, for example will only allow companies to sell in the regional e-marketplace if they are within the council boundaries.

Government agencies developing e-marketplaces should not only state their aims and objectives to suppliers but also how they plan to make it a fair marketplace. Neither of the e-marketplaces addresses this issue. The government acting as both buyer and owner may appear suspicious to some suppliers. The government in such circumstances forms a formidable power structure, hence they need to be sensitive to this perception.

\section{CONCLUSIONS}

Western Australian government sponsored e-marketplaces have the potential to narrow the digital divide both for SMEs rural and urban areas. The enormity of the challenge should not be underestimated. However, regional commissions in Western Australia examining the potential of emarketplaces should learn from the experiences of the first two governments sponsored e-marketplaces in that State. To fully harness the benefits of online business a broader vision for e-marketplaces should be considered. This should include the value of information generated, knowledge sharing and the facilitating the development of on-line business networks or clusters. A result of this would not only be a lowering of costs and access to new markets but better access to expertise and potentially higher levels of innovation.

\section{REFERENCES}

Bakos, J. Y. "Reducing Buyer Search Costs: Implications for Electronic Marketplaces", Management Science, (43:12), 1997, pp. 1676-1692.

Barrett, S., and Konsynski, B. R. "Inter-Organization Information Sharing Systems", MIS Quarterly, Special Issue (6:5), 1982, pp. 93 - 105.

Barter, C., and Renold, E. "The Use of Vignettes in Qualitative Research", Social Research Update, Issue 25, 1999, Department of Sociology, University of Surrey. Available at: http://www.surrey.ac.uk/sru/SRU25.html. 
Bebko, C. "Service Intangibility and its Impact on Consumer Expectations of Service Quality", Journal of Services Marketing, (14:1), 2000, pp. 9-26.

Berry, L., and Parasuraman, A. Marketing Services: Competing Through Quality, New York: Free Press, 1991.

Bode, S., and Burn, J. M. "Website Design Consultants, Australian SMEs and Electronic Commerce Success Factors", International Journal of Business Studies, (9:1), 2001, pp. 73-85.

Brunn, P., Jensen, M., and Skovgaard, J. "E-Marketplaces: Crafting a Winning Strategy", European Management Journal, (20:3), 2002, pp. 286-298.

Coase, R. H. "The Nature of the Firm" in The Economics of Transaction Costs, O. E. Williamson \& S. E. Masten (Eds.), Cheltenham: Edward Elgar Publishing Ltd., 1937, pp. 4-22.

Curtin, J. “A Digital Divide in Rural and Regional Australia?" Current Issues Brief 12001 2002, Department of the Parliamentary Library, Information and Research Services, 2001.

Davidson, P. "Giving Our SMEs a Fair Go!" Information Age, Oct/Nov 2002, pp. 36-47.

DoIT. "E-Commerce: A Primary Objective": Department of Industry and Trade, Western Australian Government, Available at: http://www.indtech.wa.gove.au/doit/publications/ pireport.pdf.

DoIT. "GEM", 2002, Available at: http://www.gem.wa.gov.au (Accessed at: September 24, 2002).

Erbschloe, M. "Working with SMEs in the Supply Chain", Digital Systems Report, (21:4), 1999, pp. 22-23.

Federal Trade Commission. "Entering the 21st Century: Competition Policy in the World of B2B Electronic Marketplaces: The Federal Trade Commission B2B Public Workshop", 2000.

Finch, J. "The Vignette Technique in Survey Research", Sociology, (21), 1987, pp. 105-114.

Forrester Research. "The E-Marketplace Shakeout", Forrester Research, 2000, Available at: http://www.forrester.com/ER/Baseline (Accessed at: April 19, 2001).

Jack, B. "Information Services for Profit: Small Business Embracing Net Procurement", M2 Communications Ltd, 2001. Available at: http://www.presswire.net (Accessed at: November 7, 2001).

Kaplan, S., and Sawhney, M. "E-Hubs: The New B2B Marketplaces", Harvard Business Review, May-June 2000.

Kinnes, K. "Digital Union: Digital Union Launches Free E-Market Seminar Series to Help SMEs Reap the Benefits of E-Procurement", M2 Presswire, 2001. Available at http://www.digitalunion.com/ezm.htm (Accessed at: November 7, 2001).

Korchak, R., and Rodman, R. "E-Business Adoption Among US Small Manufacturers and the Role of Manufacturing Extension", Economic Development Review, (17:3), 2001, pp.2025.

Lewis, V. "E-Commerce Ready", America's Network, (105:13), 2001, pp. 49-54.

Lucking-Reiley, D., and Spulber, D. F. "Business-to-Business Electronic Commerce", Journal of Economic Perspectives, (15:1), 2000, pp. 55-68.

McTaggart, D., Findlay, C., and Parkin, M. Economics, Sydney. Addison-Wesley, 1996.

NOIE. "Digital Divide", Canberra: National Office for the Information Economy, 2002. Available online at: http://www.noie.gov.au/publications/noie/access/connecting communities/digitaldivide.doc (Accessed at: October 20, 2002).

Oliver, C. "Determinants of Interorganisational Relationships: Integration and Future Directions", Academy of Management Review, (15:2), 1990, pp. 241-265.

Porter, M. E. "Strategy and the Internet", Harvard Business Review, March 2001, pp. 63-78.

Raisch, W. D. The eMarketplace. Strategies for Success in B2B E-Commerce, New York: McGraw Hill, 2001.

Said, A. J. "Helping Small Firms Trade Effectively with the Internet", International Trade Forum, (3), 2000, pp. 16-19. 
Sculley, A. B., and Woods, W. A. B2B Exchanges. The Killer Application in the Business-toBusiness Internet Revolution, New York: HarperCollins, 2001.

Stokes, A. "Small and Medium-Sized Enterprises and the Environment: Business Imperatives", International Small Business Journal, (19:1), 2000, pp. 100-102.

Swatman, P. "Internet for SMEs: A New Skill Road?", International Trade Forum, (3), 2000, pp. 22-24.

Tetteh, E., and Burn, J. M. "Global Strategies for SMe-Business: Applying the S-M-A-L-L Framework", Journal of Logistics and Information Management, (14:1/2), 2001, pp. 171180.

van Akkeren, J., and Cavaye, A. L. M. "Factors Affecting Entry-Level Internet Technology Adoption by Small Business in Australia - Evidence From Three Cases", Journal of Systems and Information Technology, (3:2), 1999, pp. 33-48.

Williamson, O. E. "Transaction Cost Economics: The Governance of Contractual Relations", Journal of Law and Economics, (22:2), 1979, pp. 33-261.

\section{About the Authors}

Craig Standing is Professor of Strategic Information Management at Edith Cowan University, Western Australia. He was born in the UK and achieved his $\mathrm{PhD}$ at the University of Western Australia. His research interests include the impact of e-marketplaces on organisations. He can be reached by e-mail at c.standing@ecu.edu.au.

Ian Sims is a doctoral student in the School of MIS at Edith Cowan University. He worked for many years as a procurement manager and has taught supply chain management at university level. He can be reached by email ati.simms@ecu.edu.au.

Rosemary Stockdale is a doctoral student in the School of MIS at Edith Cowan University. She is researching the use of e-marketplaces in a large mining multi-national organization. He can be reached by e-mail at r.stockdale@ecu.edu.au.

Arjen Wassenaar has been researching inter-organisational information systems for a number of years. He has published widely on the topic in IS journals and conferences. He is part of an international team studying emarketplaces. He can be reached by e-mail at d.a.wassenaar@sms. utwente.nl. 